\title{
Escherichia coli induces apoptosis and proliferation of mammary cells
}

\author{
E Long', AV Capuco², DL Wood ${ }^{2}$, T Sonstegard², G Tomita ${ }^{3}$, \\ MJ Paape ${ }^{3}$ and $X$ Zhao*,1 \\ 1 Department of Animal Science, McGill University, Ste-Anne-de-Bellevue, \\ Quebec, H9X 3V9, Canada \\ 2 Gene Evaluation and Mapping Laboratory, USDA-ARS, Beltsville, Maryland \\ 20705, USA \\ 3 Immunology and Disease Resistance Laboratory, USDA-ARS, Beltsville, \\ Maryland 20705, USA \\ * Corresponding author: X Zhao, Department of Animal Science, McGill \\ University, 21,111 Lakeshore Road, Ste-Anne-de-Bellevue, Quebec, H9X 3V9, \\ Canada. Tel: 0015143987975; Fax: 0015143987964; \\ E-mail:Xin.Zhao@mcgill.ca
}

Received 11.1.01; revised 28.2.01; accepted 28.2.01

Edited by G Nunez

\begin{abstract}
Mammary cell apoptosis and proliferation were assessed after injection of Escherichia coli into the left mammary quarters of six cows. Bacteriological analysis of foremilk samples revealed coliform infection in the injected quarters of four cows. Milk somatic cell counts increased in these quarters and peaked at $24 \mathrm{~h}$ after bacterial injection. Body temperature also increased, peaking at $12 \mathrm{~h}$ postinjection. The number of apoptotic cells was significantly higher in the mastitic tissue than in the uninfected control. Expression of Bax and interleukin- $1 \beta$ converting enzyme increased in the mastitic tissue at $24 \mathrm{~h}$ and $72 \mathrm{~h}$ postinfection, whereas Bcl-2 expression decreased at $24 \mathrm{~h}$ but did not differ significantly from the control at $72 \mathrm{~h}$ postinfection. Induction of matrix metalloproteinase-9, stromelysin-1 and urokinase-type plasminogen activator was also observed in the mastitic tissue. Moreover, cell proliferation increased in the infected tissue. These results demonstrate that Escherichia coli-induced mastitis promotes apoptosis and cell proliferation. Cell Death and Differentiation (2001) 8, 808-816.
\end{abstract}

Keywords: apoptosis; Escherichia coli; proliferation; mammary cell

Abbreviations: CFU, colony forming units; E. coli, Escherichia coli; ECM, extracellular matrix, ICE, interleukin- $1 \beta$ converting enzyme; IL-1, interleukin-1; LPS, lipopolysaccharide; MMP, matrix metalloproteinase; $\mathrm{PA}$, plasminogen activator; $\mathrm{PAI}$, plasminogen activator inhibitor; RT-PCR, reverse-transcriptase polymerase chain reaction; S. agalactiae, Streptococcus agalactiae; S. aureus, Staphylococcus aureus; SCC, somatic cell counts; SL, stromelysin; SV40 Tag, Simian virus $40 \mathrm{~T}$ antigen; TIMP, tissue inhibitor of metalloproteinase; TNF $\alpha$, tumor necrosis factor $\alpha$

\section{Introduction}

Mastitis is characterized as an inflammation of the mammary gland, primarily due to the bacterial infection through teat canals. In the past several decades, the incidence of bovine mastitis caused by contagious pathogens has been reduced dramatically. This has indirectly led to an increased percentage of mastitis caused by environmental pathogens such as Gram-negative Escherichia coli (E. coll). ${ }^{1}$ In addition, $E$. coli may induce severe mastitis that results in extensive mammary tissue damage and even, in some cases, death of the animals. ${ }^{2-5}$ Therefore, E. coli-induced bovine mastitis has become an area of intense investigation.

It is well known that two major types of cell death, namely apoptosis and necrosis, exist in almost all organisms. Apoptosis has been portrayed as a programmed cell death in response to various inducers including cytokines, bacterial toxins and loss of matrix atachment. ${ }^{6}$ During Streptococcus agalactiae (S. agalactiae)-induced mastitis, the increased expression of an apoptosis marker, TRPM-2, has been reported. ${ }^{7}$ Furthermore, Staphylococcus aureus ( $S$. aureus), one of the major contagious pathogens leading to bovine mastitis, induced apoptosis of a bovine mammary epithelial cell line. ${ }^{8}$ These studies suggest that mammary epithelial cells die via apoptosis during bovine mastitis induced by Gram-positive pathogens. However, whether E. coli causes mammary tissue damage and cell death through a similar mechanism has not been reported.

Apoptosis is regulated by a cascade of signaling events involving the coordination of many factors. The Bcl-2 family of proteins, including both pro-apoptotic (such as Bax, Bcl$\mathrm{x}_{\mathrm{S}}$, Bak and Bad) and anti-apoptotic (such as Bcl- $\mathrm{x}_{\mathrm{L}}$ and $\mathrm{Bcl}-2)$ factors, play important roles in mediating the balance between cell survival and loss in various physiological and pathological events. ${ }^{9}$ Additionally, the death signals are conducted by a family of cysteine proteases termed caspases. $^{10}$ For example, interleukin-1 $\beta$ converting enzyme (ICE), otherwise called caspase-1, is pro-apoptotic to mouse mammary epithelial cells. ${ }^{11}$

Loss of matrix attachment can also initiate apoptosis. ${ }^{6}$ Specifically, extracellular matrix (ECM) mediates cell survival and death in the mammary gland. For example, apoptosis occurred when mouse primary epithelial cells were cultured on plastic or type I collagen substrata, but the cell death was suppressed by basement membrane. ${ }^{12}$ Additionally, Merlo et $a l^{13}$ also demonstrated that purified laminin, tenascin $\mathrm{C}$, or collagen IV from ECM reduced apoptosis of a human breast epithelial cell line MCF-10A and a mouse mammary epithelial cell line HC11. Maintenance and breakdown of ECM components are regulated by the balance between the ECM-degrading proteinases and their inhibitors. For instance, altered expression of matrix metalloproteinases (MMPs) such as 
stromelysins and gelantinases and serine proteinases such as plasminogen activators (PAs) coincided with mammary cell apoptosis during involution. As well, expression of the inhibitors for these enzymes, such as tissue inhibitors of metalloproteinases (TIMPs) and plasminogen activator inhibitors (PAIs), was decreased during apoptosis of mammary cells. ${ }^{14,15}$ Conversely, expression of TIMP-1 transgene rescued the unscheduled apoptosis during late pregnancy in stromelysin-1 (SL-1) transgenic mice. ${ }^{16}$ Taken together, these results have confirmed the importance of ECM-degrading enzymes and their inhibitors in regulation of programmed mammary cell death. However, the association of ECM breakdown and cell apoptosis was mostly demonstrated during mammary involution. Whether ECM degradation is involved in tissue damage and cell death during pathological events such as $E$. coli-induced mastitis has not been extensively documented.

Cell number is dependent on not only cell death, but also proliferation. Therefore, it is also important to investigate the alteration of cell proliferation during mastitis. Although a previous in vitro study demonstrated inhibition of bovine mammary epithelial cell growth by $E$. coli endotoxin and $S$. aureus $\alpha$-toxin, ${ }^{17}$ impact of experimentally induced $E$. coli mastitis on cell proliferation in bovine mammary gland has not been elucidated.

In the present study, mammary cell proliferation and death during $E$. coli-induced bovine mastitis were investigated. Expression of $\mathrm{Bcl}-2$-related proteins and ICE was evaluated. In addition, alteration of ECM-degrading enzymes and their inhibitors was examined.

\section{Results}

\section{E. coli challenge induced intramammary infection}

Five hundred colony-forming units (CFU) of $E$. coli were injected into the left quarters of six healthy lactating cows. As a result, the left quarters of four cows were infected by $E$. coli, as proven by bacteriological analysis of foremilk samples obtained $12 \mathrm{~h}$ and $24 \mathrm{~h}$ after bacterial injection, as well as the increases in milk somatic cells counts (SCC) and rectal temperature. Compared to samples collected prior to injection $\left(1.79 \pm 0.63 \times 10^{5}\right.$ cells $\left./ \mathrm{ml}\right)$, mean milk SCC increased at $12 \mathrm{~h}$ postinjection $\left(3.51 \pm 0.46 \times 10^{6} \mathrm{cells} / \mathrm{ml}, P<0.01\right)$ and peaked at $24 \mathrm{~h}$ postinjection $\left(1.10 \pm 0.25 \times 10^{7}\right.$ cells $\left./ \mathrm{ml}, P<0.01\right)$, decreasing gradually thereafter. By $144 \mathrm{~h}$ after bacterial injection, milk SCC $\left(1.83 \pm 1.10 \times 10^{5}\right.$ cells $\left./ \mathrm{ml}\right)$ did not differ from uninfected controls (Figure 1). Rectal temperature also increased after bacterial injection (Figure 2). The temperature peaked at $12 \mathrm{~h}$ postinjection, which was significantly higher than that of preinfected cows $\left(40.1 \pm 0.5^{\circ} \mathrm{C}\right.$ vs $38.5 \pm 0.3^{\circ} \mathrm{C}$, $P<0.05)$.

\section{Apoptosis occurred in E. coli-infected mammary glands}

In order to investigate whether mammary cells died by apoptosis, the terminal deoxynucleotidyl transferase (TdT)mediated dUTP nick end labeling (TUNEL) assay was performed. For each sample, cells were classified into three types (epithelial, stromal, and lumenal cells) and apoptotic cells were counted in 10 microscopic fields $(400 \times$ magnification). E. coli mastitis increased the percentage of apoptotic epithelial and stromal cells compared with that in uninfected glands $(P<0.05$, Table 1 and Figure 3$)$. On the other hand, percentage of apoptotic cells in the lumina did not differ between infected and uninfected quarters $(P>0.05)$.

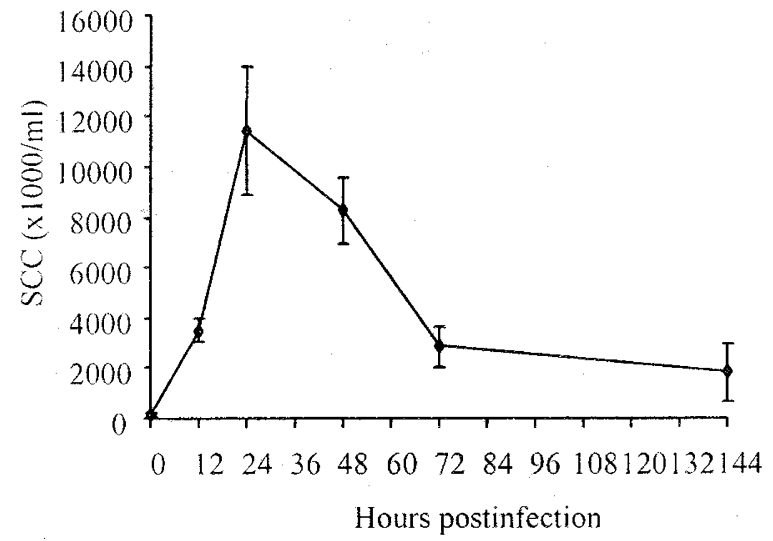

Figure 1 Milk SCC upon bacterial challenge. Left quarters were injected with $500 \mathrm{CFU}$ of $E$. coli, and SCC was measured in foremilk samples collected from the infected glands. Data are presented as the means \pm S.E.M.

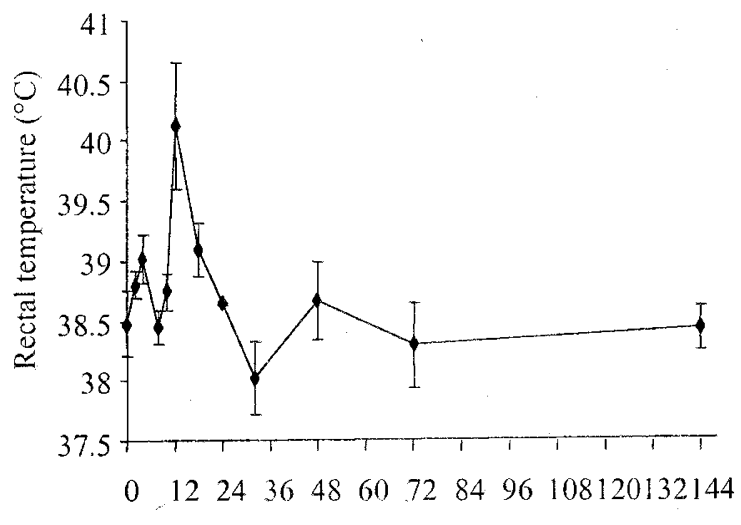

Hours postinfection

Figure 2 Rectal temperature of cows upon bacterial challenge. Left quarters were injected with $500 \mathrm{CFU}$ of $E$. coli, and rectal temperature was measured. Data are presented as the means \pm S.E.M.

Table 1 Mammary cell apoptosis induced by E. coli infection

\begin{tabular}{lcc}
\hline Cell type & $\begin{array}{c}\text { Apoptotic cells/10 microscopic fields } \\
\text { Control }\end{array}$ & Mastitic \\
\hline Epithelial & $1.80 \pm 0.5^{b}$ & $8.80 \pm 2.85^{c}$ \\
Stromal & $7.33 \pm 5.7^{b}$ & $18.00 \pm 6.79^{c}$ \\
Lumenal & $5.17 \pm 3.6^{b}$ & $5.00 \pm 1.83^{b}$ \\
\hline
\end{tabular}

${ }^{a}$ Values are means \pm S.E.M. for numbers of apoptotic cells in 10 microscopic fields. ${ }^{b,}$ Values in the same row with different superscripts statistically differ $(P<0.05)$ 


\section{Expression of $\mathrm{Bcl}-2$ family of proteins and ICE was altered during $E$. coli-induced mastitis}

Next, participation of Bcl-2 family of apoptotic regulatory genes in the induction of apoptosis during $E$. coli-induced mastitis was investigated by examining the expression of Bax, $\mathrm{Bcl}-2$ and $\mathrm{Bcl}-\mathrm{x}$ at both protein and RNA levels. Compared to uninfected controls, Western blot analysis revealed a 130 and $100 \%$ increase in Bax expression at 24 and $72 \mathrm{~h}$ after bacterial injection, respectively (Figure 4A). Conversely, Bcl-2
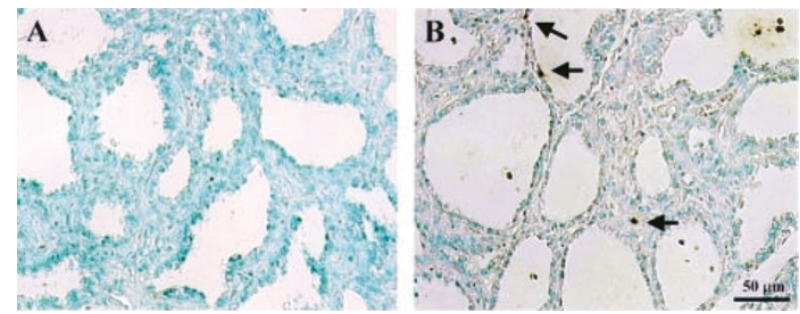

Figure 3 Detection of apoptotic cells by the TUNEL method. The apoptotic cell nuclei with brown staining (arrows) were visualized under microscope. (A) Uninfected control mammary tissue; (B) E.coli infected mammary tissue

A

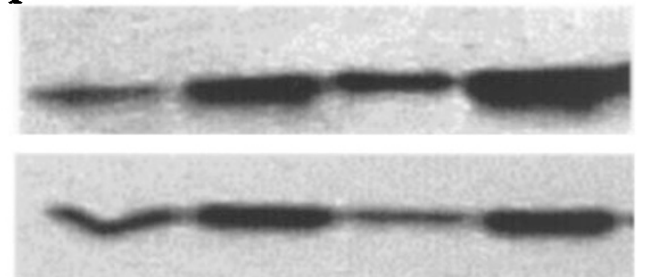

$24 \mathrm{~h}$

B

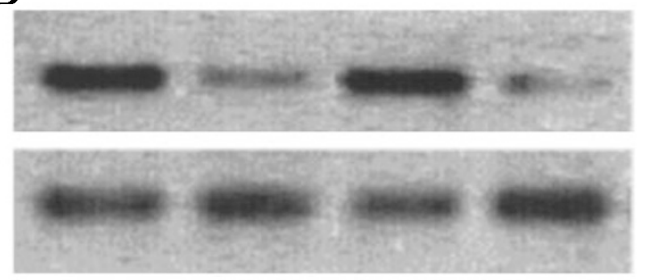

$24 \mathrm{~h}$

$\mathrm{C}$

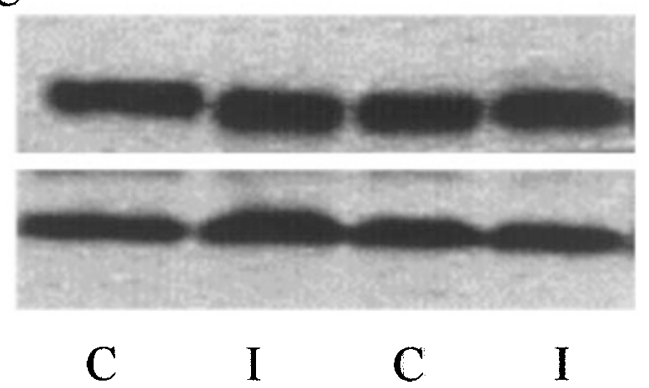

$24 \mathrm{~h}$

$72 \mathrm{~h}$

Figure 4 Protein expression of apoptosis-related genes in mammary tissue. $E$. coli infected mammary glands were biopsied at either $24 \mathrm{~h}$ or $72 \mathrm{~h}$ after bacterial challenge. The contralateral quarters were biopsied prior to challenge and served as controls. Proteins were extracted and Western blot analysis performed. C: control; I: infected. (A) Bax; (B) Bcl-2; (C) Bcl-x protein level decreased by $75 \%$ at $24 \mathrm{~h}$ postinfection, but did not differ from uninfected tissues at $72 \mathrm{~h}$ (Figure 4B). There was no significant difference in $\mathrm{Bcl}-\mathrm{X}_{\mathrm{L}}$ expression between the infected and uninfected mammary tissue samples (Figure $4 C)$.

The RNA levels of the above-mentioned genes were also detected using the reverse-transcriptase polymerase chain reaction (RT-PCR). Bax expression increased by 140 and $100 \%$ at 24 and $72 \mathrm{~h}$ postinfection, in comparison with the controls (Figure 5A). At $24 \mathrm{~h}$ after $E$. coli challenge, the RNA level of $\mathrm{Bcl}-2$ decreased $50 \%$ compared to controls, but did not differ $72 \mathrm{~h}$ postinjection (Figure 5B). Consistent with protein expression, RNA level of $\mathrm{Bcl}-\mathrm{x}_{\mathrm{L}}$ did not differ between control and infected tissues. Bcl- $\mathrm{x}_{S}$ was not detectable even after 40 cycles of PCR (Figure $5 \mathrm{C}$ ). In all cases, equal RNA loading was verified by amplifying a housekeeping gene, GAPDH (Figure 5E).

In addition to the Bcl-2 family of proteins, expression of ICE was also examined by RT-PCR. Compared to the control samples, ICE expression increased by approximately $170 \%$ at both 24 and $72 \mathrm{~h}$ postinfection (Figure $5 \mathrm{D})$.
A
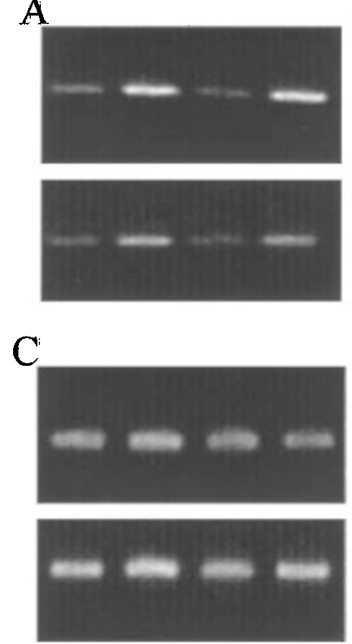

E
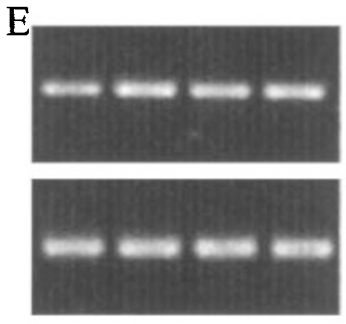

$\begin{array}{llll}\text { C } & \text { I } & \text { C } & \text { I }\end{array}$
B

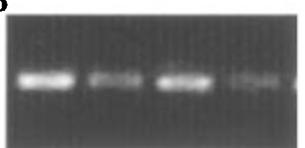

$24 \mathrm{~h}$

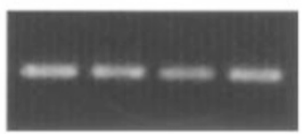

$72 \mathrm{~h}$

$\mathrm{D}$

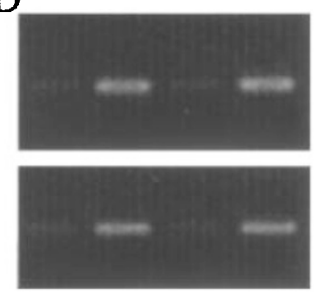

$24 \mathrm{~h}$

$72 \mathrm{~h}$
C $\quad$ I $\quad$ C $\quad$ I

$24 \mathrm{~h}$

$72 \mathrm{~h}$
Figure 5 RNA expression of apoptosis-related genes in mammary tissue. $E$. coli infected mammary glands were biopsied at either $24 \mathrm{~h}$ or $72 \mathrm{~h}$ after bacterial challenge. The contralateral quarters were biopsied prior to challenge and served as controls. RNA was extracted and subjected to RT-PCR. Equal amount of RNA loading was verified by the expression of GAPDH gene. C: control; I; infected. (A) Bax; (B) Bcl-2; (C) Bcl-x; (D) ICE; (E) GAPDH 


\section{Association of ECM-degrading enzyme expression with $E$. coli-induced mastitis}

Expression of ECM-degrading enzymes and their inhibitors during E. coli-induced mastitis was also investigated in the current study. Gelatin zymography revealed an increase in the activity of a 92-kDa gelatinase by 10 - and seven-fold at 24 and $72 \mathrm{~h}$ after bacterial challenge, as compared to the uninfected control samples (Figure 6). According to its apparent molecular weight, this enzyme was postulated as gelatinase B (MMP-9). To partially confirm this, expression of MMP-9 at the RNA level was investigated by RT-PCR. MMP-9 mRNA increased by approximately 280 and $250 \%$ at 24 and $72 \mathrm{~h}$ postinfection, as compared to control samples (Figure 7A). Furthermore, expression of SL-1, another MMP that was induced during mouse mammary involution, was investigated. SL-1 RNA increased to a lesser extent (about 50\%) than that of MMP-9 at 24 and $72 \mathrm{~h}$ after bacterial challenge (Figure 7B). Besides, uPA expression also increased by 150 and $200 \%$ at 24 and 72 h after E. coli injection (Figure 7C). Equal amount of RNA loading was verified by amplifying a housekeeping gene, GAPDH (Figure 7D).

Apart from the above-mentioned genes, the expression of tPA, TIMP-1, TIMP-2 and PAI-1 was also measured by RT-PCR. No significant difference between the infected and uninfected samples was observed (data not shown).

\section{Cell proliferation was promoted in E. coli-infected mammary glands}

In order to investigate the alteration of cell number during $E$. coli-induced mastitis, cell proliferation was also investigated by $\mathrm{Ki}-67$ immunohistochemistry. Percentage of proliferating cells labeled with $\mathrm{Ki}-67$ over total cells was arcsinetransformed to normalize the data distribution. Proliferation of all three cell types (epithelial, stromal, lumenal) was much higher in the infected glands than in controls $(P<0.05$, Table 2 and Figure 8).

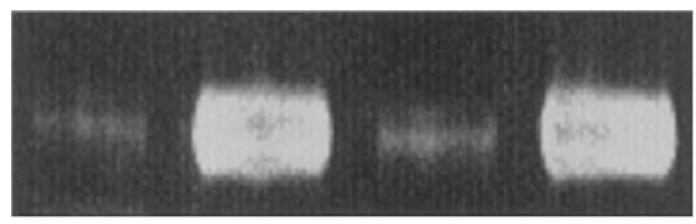

$24 \mathrm{~h}$

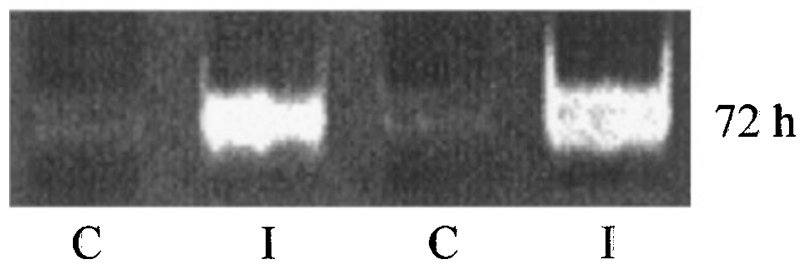

Figure 6 Expression and activity of a 92-kDa gelatinase (MMP-9). E. coli infected mammary glands were biopsied at either $24 \mathrm{~h}$ or $72 \mathrm{~h}$ after bacterial challenge. The contralateral quarters were biopsied prior to challenge and served as controls. Proteins were extracted and subjected to SDS-PAGE containing $0.1 \%$ gelatin. C: control; I: infected

\section{Discussion}

The present study demonstrated cell apoptosis in E. coliinfected bovine mammary glands, which was accompanied by increased expression of Bax and ICE, and decreased expression of Bcl-2. Expression of several ECM-degrading enzymes was also increased in the infected glands. Additionally, proliferation of mammary cells was increased during $E$. coli-induced mastitis. To our knowledge, this is
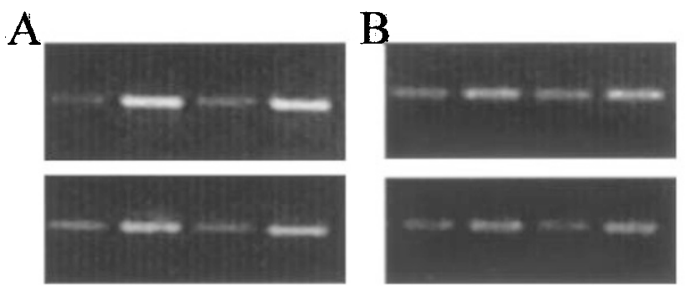

$24 \mathrm{~h}$

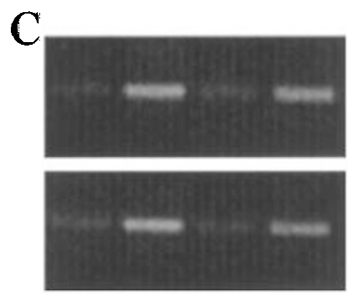

$\mathrm{D}$
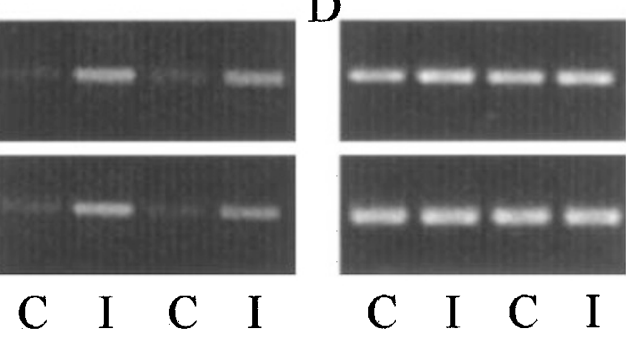

$24 \mathrm{~h}$

Figure 7 RNA expression of ECM-degrading enzymes in mammary tissue. $E$. coli infected mammary glands were biopsied at either $24 \mathrm{~h}$ or $72 \mathrm{~h}$ after bacterial challenge. The contralateral quarters were biopsied prior to challenge and served as controls. RNA was extracted and subjected to RT-PCR. Equal amount of RNA loading was verified by the expression of GAPDH gene. C: control; I: infected. (A) MMP-9; (B) SL-1; (C) UPA; (D) GAPDH

Table 2 Mammary cell proliferation induced by $E$. coli infection

\begin{tabular}{lcc}
\hline Cell type & $\begin{array}{c}\text { Arcsine transformed \% Ki-67 labeled cells } \\
\text { Control }\end{array}$ & Mastitic \\
\hline Epithelial & $0.034 \pm 0.003^{b}$ & $0.107 \pm 0.01^{c}$ \\
Stromal & $0.046 \pm 0.01^{b}$ & $0.114 \pm 0.02^{c}$ \\
Lumenal & $0.007 \pm 0.01^{b}$ & $0.046 \pm 0.0216^{c}$ \\
\hline
\end{tabular}

a Values are arcsine transformed percentage of Ki-67 labeled cells over total cells. $b$, Values in the same row with different superscripts statistically differ $(P<0.05)$
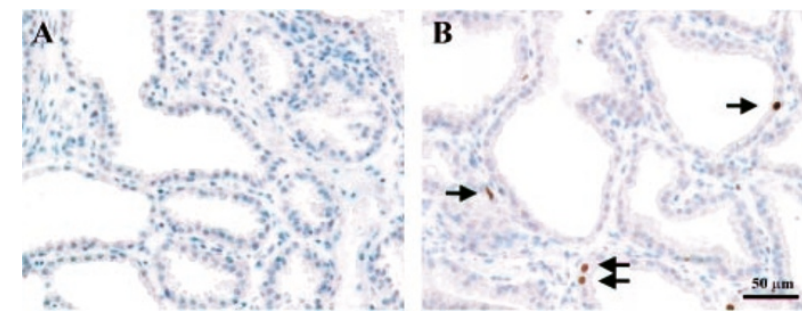

Figure 8 Detection of cell proliferation by Ki-67 staining. The Ki-67 labeled cells with brown staining (arrows) were visualized under microscope. (A) Uninfected control mammary tissue; (B) E. coli infected mammary tissue 
the first study to provide evidence that $E$. coli infection induces cell death via apoptosis in lactating mammary glands.

Increased apoptosis of mammary cells in mastitic glands was probably induced by the up-regulation of pro-apoptotic factors, Bax and ICE. Involvement of Bax in regulation of mammary cell apoptosis has been documented extensively. For instance, Bax expression was induced at the onset of mouse mammary involution, which was accompanied by programmed cell death. ${ }^{18-20}$ Premature apoptosis during pregnancy in mice carrying a Simian virus $40 \mathrm{~T}$ antigen (SV40 Tag) transgene was associated with a steady level of Bax expression. ${ }^{21,22}$ Loss of functional Bax reduced apoptosis by $20 \%$ in the first stage of mouse mammary involution. ${ }^{23}$ Participation of ICE in mammary cell apoptosis has also been suggested in previous studies. At day 2 of mouse mammary involution, when programmed cell death started to be observed, ICE expression was up-regulated. ${ }^{14}$ Moreover, inhibition of ICE reduced apoptosis induced by loss of ECM or anti-Fas in mouse or human mammary epithelial cells. ${ }^{11,24}$

In addition to the alteration of Bax and ICE expression, downregulation of $\mathrm{Bcl}-2$ may also contribute to apoptosis during $E$. coli mastitis, since its anti-apoptotic effect has been very well documented. Ectopic expression of $\mathrm{Bcl}-2$ in mammary epithelial cells completely prevented apoptosis induced by serum and grow-factor withdrawal. ${ }^{13}$ In MCF-7 cells, induction of apoptosis by bFGF overexpression was accompanied by downregulation of $\mathrm{Bcl}-2$ expression. ${ }^{25}$ Moreover, apoptosis was suppressed by 50 and $70 \%$ in Bcl-2 transgenic mice during the first and second stages of involution, respectively. ${ }^{23}$

$\mathrm{Bcl}-2$ expression in mouse lactating mammary gland was detected by Merlo et al, ${ }^{13}$ but not by other researchers. ${ }^{19,20}$ In our experiments, Bcl-2 expression was detected in bovine lactating mammary glands at both protein and RNA levels. The discrepancy from different studies may be due to differences in genetic regulation between different species, or different breeds within the same species. Weak Bcl-2 expression was also detected in sheep mammary tissue at the first day of cessation of lactation, when alveolar structure remained almost as intact as that of the lactating stage. ${ }^{26}$ It has been suggested that Bcl-2 is expressed by ductal but not secretory alveolar epithelial cells in mice, ${ }^{12}$ thus, ruminants and some mouse strains may have higher percentages of ductal cells during lactation than other mouse strains, which results in variation of $\mathrm{Bcl}-2$ expression. Nevertheless, the difference in $\mathrm{Bcl}-2$ expression reported by different research groups may also be ascribed to distinct experimental conditions. In the Western blot analyses conducted by us and Merlo et $\mathrm{al}^{13}{ }^{13}$ at least $80 \mu \mathrm{g}$ of proteins were used in SDS-gel electrophoresis, whereas Metcalfe et $a l^{19}$ only applied $20 \mu \mathrm{g}$ of total proteins in their study.

The unaltered expression of $\mathrm{Bcl}-\mathrm{x}_{\mathrm{L}}$ suggested that this gene did not regulate the apoptosis induced by $E$. coli infection of the mammary tissue. Consistent with another investigation, $\mathrm{Bcl}-\mathrm{x}_{S}$ was undetectable in lactating mammary glands by RT-PCR. ${ }^{19}$ However, Heermeier et al ${ }^{18}$ reported low level expression of $\mathrm{Bcl}-\mathrm{X}_{\mathrm{S}}$ in mouse lactating mammary gland. This discrepancy may be due to higher assay sensitivity in the latter study by combining DNA hybridization with RT-PCR.

Expression of MMP-9, SL-1 and UPA was increased in association with apoptosis during $E$. coli mastitis. MMP-9 can be produced by bovine neutrophils as well as human mammary and airway epithelial cells. ${ }^{27-30}$ Furthermore, an established bovine mammary epithelial cell line, MAC-T also produced MMP-9, as detected by gelatin zymography in the current study (data not shown). As shown in the current study, MMP-9 was expressed at a very low level in healthy bovine lactating glands. Upon $E$. coli infection, it is possible that mammary epithelial cells increase the expression of MMP-9 upon stimulation by pro-inflammatory mediators such as interleukin-1 (IL-1) and tumor necrosis factor $\alpha(\mathrm{TNF}-\alpha)$, which are induced during $E$. coli mastitis. ${ }^{31}$ As reported by Roh et al, ${ }^{32}$ MMP-9 production by human smooth muscle cells was increased by IL-1 $\beta$ and TNF- $\alpha$. Alternatively, elevated MMP-9 expression may be due to an increase in the neutrophil population of the mammary tissue since neutrophils are recruited and rapidly migrate to the site of local infection, ${ }^{4}$ as evidenced by increased milk SCC after exposure to E. coli. Cytokines induced by $E$. coli challenge could also stimulate neutrophils to express more MMP-9. It is also worth noting that gelatin zymography revealed a much higher increase (10- and sevenfold at 24 and $72 \mathrm{~h}$ postinfection, respectively) of MMP-9 than did RT-PCR (3- and 2.5-fold increase at 24 and $72 \mathrm{~h}$ postinfection, respectively). This may be a reflection of increased enzyme activity in addition to the up-regulation of gene expression. However, it can also be due to differences in translational efficiency or mRNA half-life of this enzyme between the uninfected and infected glands. SL-1, whose expression correlated with apoptosis during mammary involution, ${ }^{14}$ contributed to the breakdown of most ECM components including laminin and collagen type IV. ${ }^{33}$ These components have been viewed as survival factors in mammary tissue. ${ }^{13} \mathrm{SL}-1$ expression could also be induced by $\mathrm{IL}-1$, as shown in cardiac fibroblasts and human endometrial cells. ${ }^{34,35}$ Expression of UPA was shown to be stimulated in bovine mammary epithelial cells by $S$. aureus, a major contagious pathogen resulting in mastitis. ${ }^{36}$ Likewise, the stimulatory effect of $E$. coli mastitis on UPA expression has been demonstrated in the current study. In PC-3 human prostatic cancer cells, lipopolysaccharide (LPS), a bacterial endotoxin which can be released by $E$. coli, increased UPA expression. ${ }^{37}$ It remains to be demonstrated whether LPS or the proinflammatory cytokines induced by $E$. coli are responsible for the production of ECM-degrading enzymes in the bovine mammary gland.

While it is clear that $E$. coli infection induced programmed cell death in the mastitic mammary tissue, the extracellular mediators of this effect are unknown. One candidate is LPS released by $E$. coli. Although the total pathogenesis of $E$. coli mastitis was probably not reproducible by LPS administration, infusion of LPS did lead to many clinical aspects of $E$. coli infection. ${ }^{4}$ The proapoptotic effect of LPS has been shown on Caco-2 human intestinal epithelial cells ${ }^{38}$ and bovine glomerular endothe- 
lial cells. ${ }^{39}$ Accordingly, LPS may exert a similar effect on cell death in the mammary tissue. However, in vitro, LPS did not cause tissue damage in explants of lactating bovine mammary tissue ${ }^{40}$ but stimulated the expression of IL-1 by MAC-T cells. ${ }^{41}$ Furthermore, $E$. coli infusion into bovine mammary glands also induced production of pro-inflammatory cytokines, including IL- 1 and TNF- $\alpha .^{31,42}$ TNF- $\alpha$ and IL1 induced programmed cell death in a variety of cell types, such as bovine endothelial cells ${ }^{39}$ and human mammary, intestinal, bronchial and endometrial epithelial cells. ${ }^{38,43-45}$ Therefore, the increased apoptosis in $E$. coli-infected mammary gland may be attributable to $E$. coli- or LPSinduced proinflammatory cytokines.

Apart from increased apoptosis, cell proliferation was also promoted during $E$. coli mastitis. This may as well be accounted by the signaling mediators triggered by LPS or the cytokines. It is not uncommon that one gene may have a dual effect on proliferation and apoptosis. For instance, expression of SV40 Tag in mouse mammary glands induced unscheduled apoptosis of a large amount of cells during the pregnancy period. Nevertheless, the surviving cells underwent deregulated growth and resulted in tumor formation after the first pregnancy. ${ }^{21,22}$ As well, Bcl-2 was shown to be anti-proliferative in addition to its anti-apoptotic function. ${ }^{46}$ In our study, the decrease of Bcl-2 expression at $24 \mathrm{~h}$ postinfection may in part account for the increased rate of cell proliferation. Furthermore, apart from its role in ECM degradation and apoptosis induction, SL-1 was suggested to play an important role in mammary tumorigenesis, ${ }^{33}$ indicating its potential function in promoting cell proliferation.

Increased cell proliferation during coliform mastitis may serve as a mechanism to ameliorate tissue damage. Although E. coli may induce severe clinical symptoms, most infected cows will eliminate the bacteria and undergo self-cure. ${ }^{2-5}$ While bacterial toxins, or the proinflammatory mediators, may cause cell death by apoptosis, increased cell proliferation may compensate for the cell loss during inflammation. Interestingly, a previous study also showed an increase in DNA synthesis with the induction of bovine mammary involution by milk stasis, when mammary cell apoptosis was typical. ${ }^{47}$

The signaling events involved in mammary cell apoptosis and proliferation induced by $E$. coli infection are still not fully understood. The ligands, receptors, and genes participating in transmitting the death and proliferating signals have not been clarified. Recently, it was reported that $S$. aureus induced mammary cell apoptosis through a mechanism involving caspases 3 and $8 .{ }^{48}$ Elucidation of mechanims leading to apoptosis and cell proliferation during $E$. coli mastitis requires further study.

In summary, E. coli infection caused programmed cell death in mastitic tissue. Bax, ICE and Bcl-2 may play important roles in regulating the cell death and survival. Alteration of MMP-9, SL-1 and UPA expression was associated with cell apoptosis, suggesting that ECM degradation may partially account for the cell loss during mastitis. Proliferation of cells was also stimulated, which may be part of the self-cure mechanism after $E$. coli infection.

\section{Materials and Methods}

\section{Animals}

Six healthy mid-lactating Holstein cows from the Beltsville Agricultural Research Center dairy herd (Beltsville, MD, USA) were selected for this study. Selection criteria included noninfected mammary quarters and milk SCC less than $250 \times 10^{3}$ cells $/ \mathrm{ml}$ at the time of bacterial challenge exposure. Use of animals for this investigation was approved by the Beltsville Agricultural Research Center's Animal Care and Use Committee.

\section{Sample collection}

Quarter foremilk samples for the determination of SCC and for bacteriological examination were collected aseptically twice a week for several weeks before bacterial challenge exposure. Milk SCC in all mammary quarters were consistently less than $250 \times 10^{3} \mathrm{cells} / \mathrm{ml}$ and mammary quarters were free from intramammary infection.

$E$. coli challenge exposure was performed immediately after a specified morning milking. Foremilk samples for bacteriological examination and SCC determination were collected immediately before $E$. coli challenge exposure, to establish a base line, and at the next five milkings (12, 24, 48, 72 and $144 \mathrm{~h}$ ). Clinical observations, including rectal temperature, milk appearance, udder palpation and the general condition of the cows, were made just before bacterial injection and at the same time points, after injection, as the milk sample collections. Rectal temperatures were additionally taken at 2 , 4,8 and $10 \mathrm{~h}$ postinjection.

The challenged rear quarters of three cows were biopsied $24 \mathrm{~h}$ after bacterial injection from the upper half of the gland, while biopsies from the other three cows were obtained $72 \mathrm{~h}$ after bacterial injection, using the biopsy method described by Farr et al. ${ }^{49}$ The biopsies contained cores of the secretory tissue. A portion of each tissue biopsy was immediately snap frozen in liquid nitrogen and stored at $-80^{\circ} \mathrm{C}$ until protein or RNA extraction. The remaining tissue was placed in 10\% neutral-buffered formalin for immunohistochemical analyses. The tissue was fixed at $4^{\circ} \mathrm{C}$ overnight and then processed for paraffin embedding and sectioning. Biopsies from the right rear quarters of all six cows were obtained prior to $E$. coli injection as control samples.

\section{Intramammary challenge exposure}

The organism used was a serum-resistant E. coli, strain P-4, serotype $\mathrm{O} 32: \mathrm{H} 37$, which originally had been recovered from a cow with clinical mastitis ${ }^{50}$ and had been used in studies of $E$. coli mastitis. ${ }^{51}$ Before the challenge exposure, a tube of brain-heart infusion broth (Baltimore Biological Laboratories, Division of Becton, Dickinson \& Co., Cockeysville, MD, USA) was inoculated with lyophilized $E$. coli and incubated for $18 \mathrm{~h}$ at $37^{\circ} \mathrm{C}$. The resulting broth culture was streaked onto a Trypticase soy blood agar plate to determine its purity. After incubation, several colonies were transferred to $10 \mathrm{ml}$ of Todd-Hewett broth, incubated for $6 \mathrm{~h}$ at $37^{\circ} \mathrm{C}$ and refrigerated. On the basis of consistency of bacterial population in cultures, the challenge-exposure inoculum was prepared, using serial dilutions in sterile distilled water and a final dilution in low-endotoxin Earle's balanced salt solution. The desired challenge-exposure inoculum was $250 \mathrm{CFU} / \mathrm{ml}$. Bacterial challenge exposure in each cow was performed immediately after the specified milking, by gentle injection of a 2-ml volume (500 CFU) of the prepared inoculum into the gland sinus of left front and left rear mammary quarters. 


\section{Bacterial culture}

Each foremilk sample was plated in a $0.05-\mathrm{ml}$ volume onto Trypticase soy blood agar for identification of $E$. coli and purity. Infection was defined as recovery of $E$. coli from at least two consecutive samples with a concurrent increase in SCC.

\section{Determination of SCC}

Foremilk samples were heated for $15 \mathrm{~min}$ at $60^{\circ} \mathrm{C}$ and maintained at $40^{\circ} \mathrm{C}$ until being counted (Fossomatic 90; Foss Electric, Hilleroed, Denmark). The cell counter was calibrated monthly with bovine milk somatic cell standards (Dairy Quality Control Institute Services, Mountain View, MN, USA). Duplicate counts were made on each milk sample.

\section{In situ detection of apoptotic cells and Ki-67 immunolocalization}

After fixation at $4{ }^{\circ} \mathrm{C}$ overnight, tissues were placed in $70 \%$ ethanol, embedded in paraffin and sectioned at $6 \mu \mathrm{m}$ according to standard procedures.

Apoptotic cells in histological sections were detected by the TUNEL assay using the Apoptag kit (Intergen, Purchase, NY, USA), as previously described with slight modifications. ${ }^{52}$ In brief, tissue sections were deparaffinized and hydrated, next they were treated with $20 \mu \mathrm{g} / \mathrm{ml}$ of proteinase $\mathrm{K}$ in phosphate-buffered saline (PBS) for $15 \mathrm{~min}$ and quenched in $2 \% \mathrm{H}_{2} \mathrm{O}_{2}$ in PBS for 10 min at room temperature. Tissue sections were incubated with terminal deoxynucleotidyl transferase for $60 \mathrm{~min}$ at $37^{\circ} \mathrm{C}$, washed, and then incubated with anti-digoxigeninperoxidase for $30 \mathrm{~min}$ at room temperature. Following the reaction and color development with diaminobenzidine, sections were counterstained with methyl green $(0.1 \%$ in acetate buffer, $\mathrm{pH} 4.0)$ and mounted with Permaslip (Alban Scientific Inc., St. Louis, MO, USA). Apoptotic cells were visualized and counted microscopically.

Immunolocalization of $\mathrm{Ki}-67$ antigen was performed following the instruction provided by the manufacturer of the primary antibody (Zymed Laboratories, San Francisco, CA, USA). Briefly, slides were deparaffinized, hydrated, quenched with $3 \% \mathrm{H}_{2} \mathrm{O}_{2}$ in phosphate buffered saline (PBS) for $10 \mathrm{~min}$, washed in PBS, and heat-treated in a microwave oven for antigen retrieval in $10 \mathrm{mM}$ citrate buffer $(\mathrm{pH} \mathrm{6.0)}$. Slides were washed in PBS and blocked with $5 \%$ non-immune goat serum in PBS. The MIB-1 monoclonal antibody (Zymed) and Histostain SP kit (Zymed) was used for immunolocalization of Ki-67 antigen. Slides were incubated with the primary antibody for $60 \mathrm{~min}$ at room temperature with the biotinylated secondary antibody, washed in PBS, and then incubated with the steptavidin-peroxidase-conjugate for $10 \mathrm{~min}$ at room temperature. After washing in PBS, sections were incubated with diaminobenzidine, counter stained with hematoxylin and mounted with Permaslip.

\section{Protein extraction}

Ten $\mathrm{mg}$ of frozen tissues were homogenized in $500 \mu$ l of RIPA buffer (50 mM Tris- $\mathrm{HCl}, 150 \mathrm{mM} \mathrm{NaCl}, 1 \%$ Nonidet-P 40, 0.5\% sodium deoxycholate and $0.1 \%$ SDS, pH 8.0) containing 2 mM PMSF, $20 \mu \mathrm{g} /$ $\mathrm{ml}$ of leupeptin, $10 \mu \mathrm{g} / \mathrm{ml}$ of pepstatin, $10 \mu \mathrm{g} / \mathrm{ml}$ of aprotinin and $1 \mathrm{mM}$ $\mathrm{NaF}$, using a high shear homogenizer (Tissuemizer Mark II T25, Tekmar Company, Cincinnati, OH, USA). Samples were kept on ice for $15 \mathrm{~min}$, vortexed vigorously for $1 \mathrm{~min}$, and then centrifuged at $13000 \times g$ for $15 \mathrm{~min}$ at $4^{\circ} \mathrm{C}$. Supernatants were collected and protein concentrations were quantitated by BCA protein assay (Pierce, Rockford, IL, USA).

\section{Western blot analysis}

Expression of $\mathrm{Bcl}-2, \mathrm{Bax}$ and $\mathrm{Bcl}-\mathrm{x}$ proteins in the mammary tissues was investigated by Western blot analysis. A mouse anti-Bax monoclonal antibody (clone 2D2, Zymed), a mouse anti-Bcl-2 monoclonal antibody (NCL-bcl-2, Novacastra, Newcastle, UK) and a rabbit anti-Bcl-x polyclonal antibody (Transduction Laboratories, Lexington, KY, USA) were used. Except for Bcl-2 detection, where $100 \mu \mathrm{g}$ of proteins were applied, $50 \mu \mathrm{g}$ of proteins from each sample were electrophoretically separated on a $14 \%$ SDS-polyacrylamide gel (NOVEX, San Diego, CA, USA). Afterwards, proteins were transferred onto a P-immobilon PVDF membrane (Millipore, Bedford, MA, USA) using an electro-transblot apparatus (NOVEX). The membrane was blocked in Tris-buffered saline containing 0.05\% Tween-20 (TBS-T, $\mathrm{pH} 7.6$ ) with $5 \%$ non-fat milk powder for $1 \mathrm{~h}$ at room temperature, and followed by incubation with the primary antibodies at different dilutions (1:500 for anti-Bax, 1:50 for anti-Bcl-2 and 1:1000 for anti-Bcl-x) in TBS-T with $1 \%$ bovine serum albumin for $1 \mathrm{~h}$. After three washes with TBS-T for $5 \mathrm{~min}$ each, the membrane was incubated with secondary antibodies (1:1000 diluted in TBS-T, Santa Cruz Biotechnology, Inc., Santa Cruz, CA, USA) for $45 \mathrm{~min}$. The membrane was then washed three times in TBS-T for $10 \mathrm{~min}$ each. Proteins were detected by the enhanced chemiluminescence (ECL) method following the manufacturer's instructions (Amersham, Arlington Heights, IL, USA). Intensity of the protein bands was densitometrically quantitated using the Kodak 1D Image Analysis Software (Eastman Kodak Company, Rochester, NY, USA).

\section{Total RNA isolation}

Ten $\mathrm{mg}$ of frozen tissues were lysed in $1 \mathrm{ml}$ of RNA STAT-60 (Tel-test Inc, Friendswood, TX, USA) using a Takmar homogenizer. Two hundred $\mu \mathrm{l}$ of chloroform were added to each $\mathrm{ml}$ of cell lysate, and mixed thoroughly by vigorous shaking for $15 \mathrm{~s}$. After $2-3 \mathrm{~min}$, the sample mixture was centrifuged at $12000 \times g$ for $15 \mathrm{~min}$ at $4^{\circ} \mathrm{C}$. The aqueous phase was transferred into a clean tube and incubated with $500 \mu \mathrm{l}$ of isopropyl alcohol for $5 \mathrm{~min}$. The RNA was precipitated by centrifugation at $12000 \times \mathrm{g}$ for $10 \mathrm{~min}$ at $4^{\circ} \mathrm{C}$. Afterwards, the RNA was washed with $1 \mathrm{ml}$ of $75 \%$ ethanol by gentle vortexing, and then centrifuged at $7500 \times g$ for 5 min at $4^{\circ} \mathrm{C}$. RNA pellets were air-dried for 5-10 $\mathrm{min}$, dissolved in $0.1 \%$ diethylpyrocarbonate-treated water, and stored at $-80^{\circ} \mathrm{C}$.

\section{RT - PCR}

The mRNA levels of pro-apoptotic and anti-apoptotic factors (ICE, $\mathrm{Bax}, \mathrm{Bcl}-2$ and $\mathrm{Bcl}-\mathrm{x}$ ), as well as ECM-degrading enzymes and their inhibitors were examined by RT-PCR. Reverse transcription of total RNA was performed following the instructions provided by the manufacturer (Gibco BRL, Burlington, Ont, Canada) of the Superscript II ${ }^{\mathrm{TM}} \mathrm{RNase} \mathrm{H}^{-}$reverse transcriptase (RT). Briefly, $2 \mu \mathrm{g}$ of total RNA were incubated with $0.5 \mu \mathrm{g}$ of Oligo (dT) ${ }^{12-18}$ (Gibco BRL) in $20 \mu \mathrm{l}$ of reaction mixture containing $50 \mathrm{mM}$ Tris- $\mathrm{HCl}(\mathrm{pH} 8.3), 75 \mathrm{mM}$ $\mathrm{KCl}, 3 \mathrm{mM} \mathrm{MgCl} 2,10 \mathrm{mM}$ DTT, $500 \mu \mathrm{M}$ dNTPs (Pharmacia, Baie d'Urfé, Que, Canada) and $200 \mathrm{U}$ of RT at $42^{\circ} \mathrm{C}$ for $50 \mathrm{~min}$. The RT reaction product was then amplified by polymerase chain reaction (PCR) with gene-specific primers and annealing temperatures (Table 3). The number of PCR cycles for each gene amplification was optimized to lie within the linear range and hence was also genedependent (Table 3). The $50 \mu \mathrm{l}$ reaction mixture consisted of $20 \mathrm{mM}$ Tris- $\mathrm{HCl}$ ( $\mathrm{pH}$ 8.4), $50 \mathrm{mM} \mathrm{KCl}, 1.5 \mathrm{mM} \mathrm{MgCl}_{2}, 200 \mu \mathrm{M}$ dNTPs, $0.5 \mu \mathrm{M}$ primers, $2 \mu \mathrm{l}$ of RT reaction product and $2.5 \mathrm{U}$ of Taq DNA polymerase (Gibco BRL). The PCR amplification was preceded by sample denaturation for $5 \mathrm{~min}$ at $94^{\circ} \mathrm{C}$. Each cycle contained a denaturation 
Table 3 Primers and annealing temperatures used in RT-PCR

\begin{tabular}{|c|c|c|c|c|}
\hline Gene & $\begin{array}{l}\text { Genbank } \\
\text { Access No }\end{array}$ & Primer sequence $\left(5^{\prime}-3^{\prime}\right)$ & $\begin{array}{l}\text { No. of } \\
\text { cycles }\end{array}$ & $\begin{array}{l}\text { Annealing } \\
\text { Temperature }\end{array}$ \\
\hline Bax & U92569 & $\begin{array}{l}\mathrm{S}^{\mathrm{b}}: \text { TGAGCAGATCATGAAGACAGGG } \\
\mathrm{A}^{\mathrm{b}}: \text { TGAGCACTCCAGCCACAAAGA }\end{array}$ & 28 & $60^{\circ} \mathrm{C}$ \\
\hline $\mathrm{Bcl}-2$ & U92434 & $\begin{array}{l}\text { S:GATGACTTCTCTCGGCGCTAC } \\
\text { A:AGTGCCTTCAGAGACAGCCAG }\end{array}$ & 34 & $60^{\circ} \mathrm{C}$ \\
\hline $\mathrm{Bcl}-\mathrm{x}^{\mathrm{c}}$ & & $\begin{array}{l}\text { S:GGCAGCCGATGAGTTTGACCTG } \\
\text { A:CATGCCCGTCAGGAACCAGC }\end{array}$ & 32 & $64^{\circ} \mathrm{C}$ \\
\hline $\mathrm{ICE}^{\mathrm{C}}$ & & $\begin{array}{l}\text { S:TTCATGTCTCATGGAATTCGG } \\
\text { A:TCCTCCAAGTCACAAGACCAG }\end{array}$ & 34 & $58^{\circ} \mathrm{C}$ \\
\hline SL-1 & AF069642 & $\begin{array}{l}\text { S:TCTTCCTTCAGGCATAGATGC } \\
\text { A:AACAGCATCCACCTCTGATTC }\end{array}$ & 34 & $56^{\circ} \mathrm{C}$ \\
\hline UPA & X80851 & $\begin{array}{l}\text { S:GGAATGGTCACTCTTACCGAG } \\
\text { A:AACAATCTTAAAGCGAGGCCT }\end{array}$ & 32 & $58^{\circ} \mathrm{C}$ \\
\hline TPA & X85800 & $\begin{array}{l}\text { S:GAAGACAGAGTTCCTGTGCGTG } \\
\text { A:CACAGTACCTCCCAGGTCAGCTG }\end{array}$ & 32 & $60^{\circ} \mathrm{C}$ \\
\hline TIMP-1 & S70841 & $\begin{array}{l}\text { S:TGAAACTGCCTTATACCAGCG } \\
\text { A:AGTGAGTGTCGCTCTGCAGTT }\end{array}$ & 32 & $58^{\circ} \mathrm{C}$ \\
\hline TIMP-2 & AF144764 & $\begin{array}{l}\text { S:ACTCTGGCAACGACATCTACG } \\
\text { A:TCTTGATGCAGGCGAAGAACT }\end{array}$ & 32 & $58^{\circ} \mathrm{C}$ \\
\hline PAl-1 & X16383 & $\begin{array}{l}\text { S:ATCCAAGAGGCAATGCAATTC } \\
\text { A:GCTGAGAGTGTTCCCGTGGTA }\end{array}$ & 32 & $60^{\circ} \mathrm{C}$ \\
\hline GAPDH & U85042 & $\begin{array}{l}\text { S:CTGGCAAAGTGGACATTGTCGCC } \\
\text { A:CTTGGCAGCGCCGGTAGAAGC }\end{array}$ & 24 & $60^{\circ} \mathrm{C}$ \\
\hline
\end{tabular}

aExcept for $\mathrm{Bcl}-\mathrm{x}$ and ICE, all primers were designed based on the sequences obtained from GenBank (NCBI/EMBL). ${ }^{b} \mathrm{~S}$ : sense primer; A: antisense primer. ${ }^{C} \mathrm{BCl}-\mathrm{x}$ and ICE primers were designed based on the sequences reported by Rueda et al. ${ }^{53}$

period for $45 \mathrm{~s}$ at $94^{\circ} \mathrm{C}$, an annealing step for $30 \mathrm{~s}$ (temperature was gene-dependent) and an extension period for $90 \mathrm{~s}$ at $72^{\circ} \mathrm{C}$. Following the requisite number of cycles, samples were incubated for a final $7 \mathrm{~min}$ at $72^{\circ} \mathrm{C}$. Ten $\mu \mathrm{l}$ of PCR products were electrophoresed on a $1.8 \%$ agarose gel and ethidium bromide-stained DNA was photographed under transmitted ultraviolet light using a Kodak DC120 zoom digital camera. Intensity of the bands was densitometrically quantitated using the Kodak 1D Image Analysis Software.

\section{Gelatin zymography}

Expression and activity of gelatinases were evaluated by gelatin zymography. Fifty $\mu \mathrm{g}$ of protein lysates were subjected to nonreducing SDS-polyacrylamide gel electrophoresis (PAGE) on a precast $10 \%$ Tris-Glycine gel with $0.1 \%$ gelatin (NOVEX). After electrophoresis, the gel was incubated in $1 \times$ NOVEX zymogram renaturing buffer ( $2.5 \%$ Triton $\mathrm{X}-100$ in water) with gentle agitation for $30 \mathrm{~min}$ at room temperature, followed by equilibration with zymogram developing buffer ( $10 \mathrm{mM}$ Tris Base, $40 \mathrm{mM}$ Tris $\mathrm{HCl}, 200 \mathrm{mM} \mathrm{NaCl}$, $5 \mathrm{mM} \mathrm{CaCl}_{2}$ and $0.2 \%$ Brij 35 in 1 I water) for $30 \mathrm{~min}$ at room temperature. Fresh zymogram developing buffer was then replaced and incubated with the gel at $37^{\circ} \mathrm{C}$ overnight. The next day, the gel was stained with $0.1 \%$ Coomassie Blue R-250 in acetic acid/ methanol/water $(1 / 4 / 5)$ for $30 \mathrm{~min}$, and destained in acetic acid/ methanol/water $(1 / 3 / 6)$ until the bands were clearly visualized. Intensities of the bands were quantitated using the Kodak 1D Image Analysis Software.

\section{Statistical analysis}

Statistical analysis was performed using NCSS 97 software (JL Hintze, Kaysville, Utah, USA). For milk SCC and rectal temperature of the cows, comparison of two treatment groups (infected and uninfected samples) was carried out by a paired $t$-test. For other assays, difference between the infected and uninfected samples was analyzed by the student's $t$-test. Data were expressed as means \pm standard errors of the means (S.E.M.).

\section{Acknowledgement}

This work was partially supported by a grant (155423-98) from Natural Sciences and Engineering Research Council of Canada to X Zhao.

\section{References}

1. Blowey R and Edmondson $P$ (1995) Mastitis-causes, epidemiology and control. In: Blowey Rand Edmondson P (eds) Mastitis control in dairy herds: an illustrated and practical guide. Farming Press: Ipswich, UK pp 27-45

2. Eberhart RJ (1977) Coliform mastitis. J.A.V.M.A. 170: $1160-1163$

3. Eberhart RJ, Natzke RP, Newbould FHS, Nonnecke B and Thompson P (1979) Coliform mastitis - a review. J. Dairy Sci. 62: 1-22

4. Hill AW (1994) Escherichia coli mastitis. In: Gyles CL (ed) Escherichia coli in domestic animals and humans. Cab International: Wallingford, UK pp 117-133

5. Hogan JS, Smith KL and Hoblet KH (1989) Field survey of clinical mastitis in low somatic cell count herds. J Dairy Sci 72: 1547-1556

6. Thompson CB (1995) Apoptosis in the pathogenesis and treatment of disease. Science 267: 1445-1449

7. Sheffield LG (1997) Mastitis increases growth factor messenger ribonucleic acid in bovine mammary glands. J. Dairy Sci. 80: 2020-2024

8. Bayles KW, Wesson CA, Liou LE, Fox LK, Bohach GA and Trumble WR (1998) Intracellular Staphylococcus aureus escapes the endosome and induces apoptosis in epithelial cells. Infect. Immun. 66: 336-342

9. Adams JM and Cory S (1998) The Bcl-2 protein family: Arbiters of cell survival. Science 281: 1322-1326

10. Thornberry NA and Lazebnik Y (1998) Caspases: Enemies within. Science 281: $1312-1316$

11. Boudreau N, Sympson CJ, Werb Z and Bissell MJ (1995) Suppression of ICE and apoptosis in mammary epithelial cells by extracellular matrix. Science 267:891893 
12. Pullan S, Wilson J, Metcalfe A, Edwards GM, Goberdhan N, Tilly J, Hickman JA Dive C and Streui $\mathrm{CH}$ (1996) Requirement of basement membrane for the suppression of programmed cell death in mammary epithelium. J. Cell Sci. 109: 631-642

13. Merlo GR, Cella N and Hynes NE (1997) Apoptosis is accompanied by changes in Bcl-2 and Bax expression, induced by loss of attachment, and inhibited by specific extracellular matrix proteins in mammary epithelial cells. Cell Growth Differ. 8: 251-260

14. Lund LR, Romer J, Thomasset N, Solberg H, Pyke C, Bissell MJ, Dane K and Werb Z (1996) Two distinct phases of apoptosis in mammary gland involution: proteinase-independent and -dependent pathways. Development 122: 181 193

15. Strange R, Li F, Saurer S, Burkhardt A and Friis RR (1992) Apoptotic cell death and tissue remodelling during mouse mammary gland involution. Development 115: $49-58$

16. Alexander CM, Howard EW, Bissell MJ and Werb Z (1996) Rescue of mammary epithelial cell apoptosis and entactin degradation by a tissue inhibitor of metallproteinase-1 transgene. J. Cell Biol. 135: 1669-1677

17. Matthews KR, Rejman JJ, Turner JD and Oliver SP (1994) Proliferation of a bovine mammary epithelial cell line in the presence of bacterial virulence factors. J. Dairy Sci. 77: 2959-2964

18. Heermeier H, Benedict M, Li M, Furth P, Nuñez G and Hennighausen L (1996 $\mathrm{Bax}$ and $\mathrm{Bcl}-\mathrm{x}_{\mathrm{S}}$ are induced at the onset of apoptosis in involuting mammary epithelial cells. Mech. Dev. 56: 197-207

19. Metcalfe AD, Gilmore A, Klinowska T, Oliver J, Valentijn AJ, Brown R, Ross A MacGregor G, Hickman JA and Streuli CH (1999) Developmental regulation of Bcl-2 family protein expression in the involuting mammary gland. J. Cell Sci. 112 $1771-1783$

20. Schorr K, Li M, Krajewski S, Reed JC and Furth PA (1999) Bcl-2 gene family and related proteins in mammary gland involution and breast cancer. J. Mam. Gland Biol. Neoplasia 4: 153-164

21. Li M, Hu J, Heermeier K, Hennighausen L and Furth PA (1996) Expression of a viral oncoprotin during mammary gland development alters cell fate and function induction of p53-independent apoptosis is followed by impaired milk protein production in surviving cells. Cell Growth Differ. 7: 3-11

22. Tzeng YJ, Gottlob K, Santarelli R and Graessmann A (1996) The SV40 T-antigen induces premature apoptotic mammary gland involution during late pregnancy in transgenic mice. FEBS Lett. 380: 215-218

23. SchorrK, LiM, Bar-PeledU, Lewis A, Heredia A, Lewis B, Knudson M, Korsmeye SJ, Jäger R. Weiher H and Furth PA (1999) Gain of Bcl-2 is more potent than Bax Loss in regulating mammary epithelial cell survival in vivo. Cancer Res. 592 $541-2545$

24. Keane MM, Ettenberg SA, Lowrey GA, Russell EK and Lipkowitz S (1996) Fas expression and function in normal and malignant breast cell lines. Cancer Res. 56: $4791-4798$

25. Maloof $P$, Wang $Q$, Wang $H$, Stein D, Denny TN, Yahalom J, Fenig E and Wiede R (1999) Overexpression of basic fibroblast growth factor (FGF-2) downregulates Bcl-2 and promotes apoptosis in MCF-7 human breast cancer cells. Breast Cancer Res. Treat. 56: 153-167

26. Colitti M, Stefanon B and Wilde CJ (1999) Apoptotic cell death, bax and bcl-2 expression during sheep mammary gland involution. Anat. Histol. Embryol. 28 $257-264$

27. Hazan RB, Phillips GR, Qiao RF, Norton L and Aaronson SA (2000) Exogenous expression of $\mathrm{N}$-cadherin in breast cancer cells induces cell migration, invasion and Metastasis. J. Cell Biol. 148: 779-790

28. Legrand C, Gilles C, Zahm J-M, Polette M, Buisson A-C, Kaplan H, Birembaut P and Tournier J-M (1999) Airway epithelial cell migration dynamics: MMP-9 role in cell-extracellular matrix remodeling. J. Cell Biol. 146: 517-529

29. LiX, Zhao X and Ma S (1999) Secretion of $92 \mathrm{kDa}$ gelatinase (MMP-9) by bovine neutrophils. Vet. Immunol. Immunopathol. 67: 247-258

30. Reddy KB, Krueger JS, Kondapaka SB and Diglio CA (1999) Mitogen-activated protein kinase (MAPK) regulates the expression of progelatinase $B$ (MMP-9) in breast epithelial cells. Int. J. Cancer 82: 268-273

31. Shuster DE, Lee EK and Kehrli Jr ME (1996) Bacterial growth, inflammatory cytokine production, and neutrophil recruitment during coliform mastitis in cows within ten days after calving, compared with cows at midlactation. Am. J. Vet Res. 57: 1569-1575
32. Roh CR, Oh WJ, Yoon BK and Lee JH (2000) Up-regulation of matrix metalloproteinase-9 in human myometrium during labour: a cytokine-mediated process in uterine smooth muscle cells. Mol. Hum. Reprod. 6: 96-102

33. Rudolph-Owen LA and Matrisian LM (1998) Matrix metalloproteinases in remodeling of the normal and neoplastic mammary gland. J. Mam. Gland Biol. Neoplasia 3: 177-189

34. Keller NR, Sierra-Rivera E, Eisenberg E and Osteen KG (2000) Progesterone exposure prevents matrix metalloproteinase-3 (MMP-3) stimulation by interleukin-1 alpha in human endometrial stromal cells. J. Clin. Endocrinol. Metab. 85: 1611-1619

35. Siwik DA, Chang DL and Colucci WS (2000) Interleukin-1 beta and tumor necrosis factor-alpha decrease collagen synthesis and increase matrix metalloproteinase activity in cardiac fibroblasts in vitro. Circul. Res. 86: 12591265

36. Zavizion B, White JH and Bramley AJ (1997) Staphylococcus aureus stimulates urokinase-type plasminogen activator expression by bovine mammary cells. J. Infect. Dis. 76: 1637-1640

37. Ohta S, Niiya K, Sakuragawa N and Fuse H (2000) Induction of urokinase-type plasminogen activator by lipopolysaccharide in PC-3 human prostatic cancer cells. Thrombosis Res. 97: 343-347

38. Swank GM, Lu Q, Xu D-Z, Michalsky M and Deitch EA (1998) Effect of acutephase and heat-shock stress on apoptosis in intestinal epithelial cells (Caco-2). Crit. Care Med. 26: 1213-1217

39. Mebmer UK, Briner VA and Pfeilschifter J (1999) Tumor necrosis factor- $\alpha$ and lipopolysaccharide induce apoptotic cell death in bovine glomerular endothelial cells. Kidney Int. 55: 2322-2337

40. Capuco AV, Paape MJ, Smith JJ and Loefler DA (1985) In vitro effect of bacterial toxins on lactating bovine mammary tissue. J. Dairy Sci. 68(Suppl 1): 206-207

41. Boudjellab N, Chan-Tang HS and ZhaoX (2000) Bovine interleukin-1 expression by cultured mammary epithelial cells (MAC-T) and its involvement in the release of MAC-T derived interleukin-8. Comp. Physiol. Biochem. 127: 191-199

42. Shuster DE, Kehrli Jr ME, Rainard P and Paape M (1997) Complement fragment C5a and inflammatory cytokines in neutrophil recruitment during intramammary infection with Escherichia coli. Infect. Immun. 65: 3286-3292

43. Burow ME, Tang Y, Collins-Burow BM, Krajewski S, Reed JC, McLachlan JA and Bechman BS (1999) Effects of environmental estrogens on tumor necrosis factor $\alpha$-mediated apoptosis in MCF-7 cells. Carcinogenesis 20: 2057-2061

44. Kampf C, Relova AJ, Sandler S and Roomans GM (1999) Effects of TNF-alpha, IFN-gamma and IL-1beta on normal human bronchial epithelial cells. Eur. Respir. J. 14: 84-91

45. Tanaka T, Umesaki N, Mizuno K, Chang L, Ohtaki S and Ogita S (1998) Enhancement of apoptotic susceptibility by interleukin-1 beta in human endometrial epithelial cells. Gynecol. Endocrinol. 12: 315-319

46. Furth PA, Bar-Peled U, Li M, Lewis A, Laucirica R, JägerR, WeiherH and Russell RG (1999) Loss of anti-mitotic effects of Bcl-2 with retention of anti-apoptotic activity during tumor progression in a mouse model. Oncogene 18: 6589-6596

47. Capuco AV and Akers RM (1990) Thymidine incorporation by lactating mammary epithelium during compensatory mammary growth in beef cattle. J. Dairy Sci. 73: $3094-3103$

48. Wesson CA, Deringer J, Liou LE, Bayles KW, Bohach GA and Trumble WR (2000) Apoptosis induced by Staphylococcus aureus in epithelial cells utilizes a mechanism involving caspases 8 and 3. Infect. Immun. 68: 2998-3001

49. Farr VC, Stelwagen K, Cate LR, Molenaar AJ, McFadden TB and Davis SR (1996) An improved method for the routine biopsy of bovine mammary tissue. J. Dairy Sci. 79: 543-549

50. Bramley AJ (1976) Variations in the susceptibility of lactating and non-lactating bovine udders to infection when infused with Escherichia coli. J. Dairy Res. 43: $205-211$

51. Hill AW (1981) Factors influencing the outcome of Escherichia colimastitis in the dairy cow. Res. Vet. Sci. 31: 107-112

52. Li M, Hu J, Heermeier K, Hennighausen L and Furth PA (1996) Apoptosis and remodeling of mammary gland tissue during involution proceeds through p53independent pathways. Cell Growth Differ. 7: 13-20

53. Rueda BR, Tilly KI, Botros IW, Jolly PD, Hansen TR, Hoyer PB and Tilly JL (1997) Increased bax and interleukin-1 $\beta$-converting enzyme messenger ribonucleic acid levels coincide with apoptosis in the bovine corpus luteum during structural regression. Biol. Reprod. 56: 186-193 